\title{
TRANSPARANSI PELAYANAN JAMINAN SOSIAL NASIONAL (JSN) KETENEGAKERJAAN DI KABUPATEN GOWA
}

\author{
Hidayatullah $^{1,}$ Andi Nuraeni Aksa ${ }^{2}$, Ihyani Malik ${ }^{2}$ \\ ${ }_{1}^{1}$ Program Studi Ilmu Pemerintahan Fakultas Ilmu Sosial dan Ilmu Politik \\ Universitas Muhammadiyah Makassar \\ Jl Sultan Alauddin No 259 Makassar 90221 \\ Telp. 0411-866972 ext. 107. Fax. 0411-8655888 \\ hidayatullah@yahoo.co.id \\ ${ }^{2}$ Program Studi Ilmu Adminitrasi Negara Fakultas Ilmu Sosial dan Ilmu Politik \\ Universitas Muhammadiyah Makassar \\ Jl Sultan Alauddin No 259 Makassar 90221 \\ Telp. 0411-866972 ext. 107. Fax. 0411-8655888 \\ nuraeni_aksa@yahoo.co.id ihyani_malik@yahoo.co.id
}

\begin{abstract}
This study aims to determine the transparency of the Social Security services Employment in Gowa. Penelitiian type used in this approach with a qualitative description by conducting interviews. Data collection techniques in this research is observation, interview, and documentation. The results showed that: the provision of information with clarity indicator procedures, clarity of costs already quite transparent; easy access to information with indicators of the ease of getting information directly or indirectly, is also quite easy to obtain; Develop a complaints mechanism if there are rules that have been violated or request to pay a bribe to the service indicator complaints have been made; Improving the flow of information through cooperation with mass media and non-governmental institutions have been established. Efforts are being made to bring transparency BPJS Employment services Employment WSN WSN is to provide information regarding employment through labor website, then one-stop services, namely services performed in one room and provide one-day service care provision.
\end{abstract}

Keywords: JSN employment, service

\begin{abstract}
ABSTRAK
Penelitian ini bertujuan untuk mengetahui transparansi pelayanan JSN Ketenagakerjaan di Kabupaten Gowa. Jenis yang digunakan dalam penelitiian ini adalah pendekatan deskripsi kualitatif dengan dengan melakukan wawancara. Teknik pengumpulan data dalam penelitian ini adalah observasi, wawancara, dan dokumentasi. Hasil penelitian menunjukkan bahwa: penyediaan informasi dengan indikator kejelasan prosedur-prosedur, kejelasan biaya-biaya sudah cukup transparan; kemudahan akses informasi dengan indikator kemudahan mendapatkan informasi langsung maupun tidak langsung juga cukup mudah didapatkan; Menyusun suatu mekanisme pengaduan jika ada peraturan yang dilanggar atau permintaan untuk membayar uang suap dengan indikator layanan pengaduan telah dilakukan; Meningkatkan arus informasi melalui kerjasama dengan media massa dan lembaga non pemerintah telah terjalin. Upaya yang dilakukan BPJS Ketenagakerjaan dalam mewujudkan transparansi pelayanan JSN Ketenagakerjaan adalah memberikan informasi terkait JSN Ketenagakerjaan melalui website tenagakerja, kemudian pelayanan satu atap yaitu pelayanan yang dilakukan dalam satu ruangan dan menyediakan penyediaan pelayanan one day service.
\end{abstract}

Kata kunci: JSN ketenagakerjaan, pelayanan 


\section{A. PENDAHULUAN}

Undang-undang Republik Indonesia Nomor 13 Tahun 2003 tentang ketenagakerjaan, seperti yang dijelaskan dalam pasal 5 "setiap tenaga kerja mempunyai hak dan kesempatan yang sama untuk memperoleh pekerjaan dan penghidupan yang layak tanpa membedakan jenis kelamin, suku, ras, agama, dan aliran politik sesuai dengan minat dan kemampuan tenaga kerja yang bersangkutan, termasuk perlakuan yang sama terhadap para penyandang cacat". Ketenagakerjaan dianggap sebagai bagian integral dari pembangunan nasional berdasarkan Pancasila dan Undang-undang Dasar Negara Republik Indonesia Tahun 1945, dilaksanakan dalam rangka pembangunan masyarakat Indonesia seluruhnya untuk meningkatkan harkat, martabat, dan harga diri tenaga kerja serta mewujudkan masyarakat sejahtera, adil, makmur, dan merata, baik materil maupun spiritual.

Pelayanan publik di Indonesia dan di seluruh daerah provinsi serta kabupaten/kota telah memperoleh landasan konstitusional yang diatur dalam pasal 18A "masyarakat berhak mengetahui kebenaran isi standar pelayanan", selanjutnya diimplementasikan melalui Undang-Undang No. 25 Tahun 2009 tentang pelayanan publik sehingga UndangUndang ini sudah seharusnya dalam tatanan normatif menterjemahkan atau mengimplementasikan keinginan esensi pasal 18A UUD 1945. Dengan pengertian bahwa, ketentuan pasal ini harus memuat prinsip dasar yang memungkinkan bagi terselenggaranya pelayanan masyarakat yang lebih dapat dinikmati oleh masyarakat (Husni Thamrin, 2013:27).

Asas transparansi penyelenggaraan pelayanan publik sesungguhnya merupakan masiestasi asas openbaarbied dalam konsepsi hukum administrasi di Belanda, asas ini dimaksudkan sebagai asas yang menghendaki bahwa dalam pelaksanaan tugas dan kegiatan pelayanan publik harus dilakukan secara dan bersifat terbuka bagi masyarakat yang dimulai dari pengambilan keputusan tentang kebijakan, perencanaan, sampai dengan pelaksanaan dan pengawasan atau pengendaliannya, dan tentunya tidak di tinggalkan adanya keharusan bahwa pelayanan publik tersebut dapat dengan mudah di akses oleh semua pihak yang membutuhkan informasi transparansi pemerintah merupakan sesuatu hal yang substansial, sebab dengan transparansi tersebut masyarakat dapat mendapatkan lebih banyak pengertian tentang rencana-rencana kebijakan yang dijalankan.

Eksistensi pelayanan JSN ketenagakerjaan yang transparan akan melahirkan kepercayaan publik dan berpeluang terwujudnya pelayanan yang baik. Menurut Saprianto (2005:15) menyatakan bahwa "melalui transparansi akan memberikan informasi yang terbuka dan jujur kepada masyarakat berdasarkan pertimbangan bahwa masyarakat memiliki hak untuk mengetahui secara terbuka dan menyeluruh atas pertanggung jawaban pemerintah dalam pengelolaan sumber daya yang dipercayakan kepadanya dan ketaatanya pada peraturan perundangundangan". Dengan melihat konsep yang dikemukakan oleh Saprianto, sangat besar kemungkinanya bahwa transparansi akan terwujud dalam lingkungan masyarakat terkait pelyanan JSN ketenagakerjaan jika memliki penerapan yang baik. Seperti halnya di Kabupaten Gowa, jika pelayanan JSN ketenagakerjaan memiliki transparansi yang baik kepada masyarakatnya maka proses pelayanan tersebut akan mencapai titik efektifitas yang baik.

Istilah Jaminan Sosial memang sudah sangat populer. Namun, penyelanggaraan program jaminan sosial itu sendiri substansinya sering dipahami berbeda. Dalam Sistem Jaminan Sosial, manfaat yang diberikan harus memenuhi kriteria 
tertentu bahwa dengan manfaat itu, orang akan memiliki rasa aman (security), sejak lahir hingga meninggal dunia. Kalau tidak terpenuhi kriteria ini, program jaminan sosial yang dimaksudkan itu (mungkin) adalah bantuan sosial (social assistance) atau pelayanan sosial (social serrvices) atau perlindungan sosial yang sifatnya temporer, sesuai dengan kejadian sosial yang terdapat di masyarakat, termasuk keterbatasan dalam mengakses pelayanan kesehatan, kelaparan maupun bencana alam dan lain sebagainya.

Kurangnya pemahaman masyarakat akan program kerja jaminan sosial ketenagakerjaan yang dilakukan PT Jamsostek yang memiliki kewenangan dalam pemberian jaminan sosial kepada masyarakat berdasarkan Undang-undang No. 3 tahun 1992 menjadi salah satu faktor tidak berjalannya program Jamsostek secara optimal. Dengan kenyataan seperti itu dapat dipahami bahwa perkembangan sistem jaminan sosial di Indonesia sangat lamban dan belum efektif. Jaminan sosial tenaga kerja tersebut yang menanggulangi resiko-resiko kecelakaan kerja yang pada gilirannya akan membantu meningkatkan produktivitas kerja, efisiensi, kualitas \& produktivitas kerja sangat penting dalam menunjang ilustralisasi dalam tahap pembangunan selanjutnya. Hal seperti inilah yang sangat di harapakan bisa terealisasikan di Kabupaten Gowa.

Transparansi yang disajikan dalam pelayanan JSN Ketenagakerjaan belum maksimal dan masih kurangnya bentuk trasnparansi pengelolaan pelayanan, dimana masyarakat belum mengetahui persis bagaimana sebenarnya prosedur pelayanan JSN Ketenagakerjaan di Kabupaten Gowa, serta kurangnya upaya yang dilakukan oleh pemerintah dalam mewujudkan transparansi pelayanan. Berangkat dari itu penulis tertarik melakukan penelitian mengenai Transparansi Pelayanan Jaminan Sosial Nasional (JSN) Ketenagakerjaan di
Kabupaten Gowa dan Upaya Pemerintah dalam Mewujudkan Transparansi Pelayanan JSN Ketenagakerjaan di Kabupaten Gowa.

\section{B. KONSEP TRANSPARANSI}

Transparansi dibangun atas dasar arus informasi yang bebas. Seluruh proses pemerintahan, lembaga-lembaga, dan informasi perlu dapat diakses oleh pihak-pihak yang berkepentingan dan informasi yang tersedia harus memadai agar dapat dimengerti dan dipantau. Pemerintah yang baik dan bersifat transparan terhadap rakyatnya baik ditingkat pusat maupun daerah. Menurut Andrianto (2007: 20) Transparansi adalah Keterbukaan secara sungguh-sungguh, menyeluruh, dan memberi tempat bagi partisipasi aktif dari seluruh lapisan masyarakat dalam proses pengelolaan sumber daya publik. Sedangkan Ali Faried ( 2011 : 166) mendefinisikan transparansi sebagai kebebasan arus informasi, informasi yang diterima masyarakat harus tepat, benar, dan akurat (tidak dipelintir atau direkayasa untuk kepentingan penguasa).

Menurut Logos (2003: 9) transparansi dan akuntabilitas merupakan konsep yang berkaitan erat satu dengan yang lain, karena tanpa transparansi tidak mungkin ada akuntabilitas. Sebaliknya transparansi tidak akan banyak bermanfaat tanpa dilengkapi dengan akuntabilitas. Seperti halnya di bidang kebijakan publik yang lain, keberadaan transparansi dan akuntabilitas merupakan syarat mutlak untuk membangun kebijakan dan institusi yang efektif, efisien, dan adil (equitable). Lingkup transparansi dan akuntabilitas harus menjangkau beberapa tingkat kebijakan mulai dari perumusan kebijakan, pengambilan keputusan, sampai pada pelaksanaannya yang terjadi di segenap institusi.

Transparansi (Oleh Krina P. 2003 : 14) yang mendefinisikan transparansi 
sebagai prinsip yang menjamin akses atau kebebasan bagi setiap orang untuk memperoleh informasi tentang penyelenggaraan pemerintahan, yakni informasi tentang kebijakan, proses pembuatan dan pelaksanaannya, serta hasil-hasil yang dicapai.

Menurut Hardjasoemantri (2003: 23) Transparansi adalah seluruh proses pemerintah, lembaga-lembaga, dan informasi perlu dapat diakses oleh pihakpihak yang berkepentingan, dan informasi yang tersedia harus memadai agar dapat dimengerti dan dipantau. Haryatmoko (2011: 112) yang memberikan pemahamannya terhadap konsep transparasi bahwa "organisasi pemerintah bisa mempertanggungjawabkan apa yang telah dilakukan dengan memberi informasi yang relevan atau laporan yang terbuka terhadap pihak luar atau organisasi mandiri (legislator, auditor, publik) dan dipublikasikan".

Menurut Thamrin Husni (2013 : 38) transparansi merupakan sesuatu hal yang substansial sebab dengan transparansi tersebut masyarakat dapat mendapatkan lebih banyak pengertian tentang rencanarencana kebijakan. Dari pengertian di atas dapat dipahami bahwa dalam transparansi pemerintah sesungguhnya masyarakat memiliki hak dan kesempatan untuk mengakses (mengetahui) rencana-rencana atau keputusan-keputusan yang akan diambil oleh pemerintah. Hak dan kesempatan untuk turut memikirkan, dan bahkan mungkin memutuskan suatu kebijakan pemerintahan melalui sarana peran serta. Untuk kepentingan tersebut amat di butuhka adanya informasi yang terbuka, prosedur yang memungkinkan peran serta, bagi masyarkat dan pengumuman (publication).

Adapun Indikator transparansi menurut Mardiasmo (2009: 17) yaitu prinsip yang menjamin akses atau kebebasan bagi setiap orang untuk memperoleh informasi tentang penyelenggaraan pemerintahan, yakni informasi mengenai kebijakan, proses pembuatan, pelaksanaan, dan hasil yang dicapai.

Berbagai definisi di atas penulis dapat menarik kesimpulan bahwa transparansi merupakan keterbukaan pemerintah kepada masyarakat untuk mengakses informasi berdasarkan pertimbangan bahwa masyarakat memiliki hak untuk mengetahui secara terbuka dan menyeluruh atas pertanggung jawaban pemerintah tersebut.

\section{Pengertian Konsep Pelayanan}

Pelayanan merupakan suatu bentuk sistem, prosedur atau metode tertentu diberikan kepada orang lain, dalam hal ini, kebutuhan pelanggan tersebut dapat terpenuhi sesuai dengan harapan atau keinginan pelanggan dengan tingkat persepsi mereka. Kolter (dalam Lukman 2000: 4), pelayanan adalah setiap kegiatan yang menguntungkan dalam suatu kumpulan atau kesatuan dan menawarkan kepuasaan meskipun hasilnya tidak terikat pada suatu produk secara fisik.

Sementara, Gronroos (dalam Tjiptono 1997: 13), pelayanan adalah suatu aktivitas atau serangkaian aktivitas yang bersifat tidak kasat mata (intangible) yang terjadi sebagai akibat adanya interaksi antara konsumen dengan karyawan (staf) atau hal-hal lain yang disediakan oleh perusahaan/instansi pemberi layanan yang dimaksudkan untuk memecahkan masalah konsumen/pelanggan.

Menurut Fred Luthans (dalam Moenir 2008 : 16) menjelaskan pelayanan sebagai sebuah proses pemenuhan kebutuhan melalui aktivitas orang lain yang menyangkut segala usaha yang di lakukan orang lain dalam rangka mencapai tujuan.

Berdasarkan pengertian diatas maka dapat disimpulkan bahwa pelayanan merupakan suatu bentuk sistem, prosedur atau metode tertentu diberikan kepada orang lain, dalam hal ini, kebutuhan pelanggan tersebut dapat terpenuhi sesuai 
dengan harapan atau keinginan pelanggan dengan tingkat persepsi mereka.

Memberikan pelayanan yang berkualitas kepada pelanggan merupakan hal penting yang mempengaruhi kinerja kompetitif organisasi dan kualitas maupun produktivitas yang tinggi, merupakan hal yang penting. Pelayanan berawal dari desain produk dan termasul interaksi dengan pelanggan, dengan tujuan memberikan kepuasan dalam memenuhi kebutuhan pelanggan. Jika harapan pelanggan terpenuhi, pelanggan pun lebih puas, membuat komentar yang menyenangkan orang lain atau menjadi pelanggan berulang. Sebagai akibatnya, untuk meningkatkan daya saing orgaanisasi, mereka harus bekerja untuk meningkatkan pelayanan. Pelayanan prima yang merupakan terjemahan dari excellent service berarti pelayanan yang sangat baik atau pelayanan terbaik.

\section{Konsep Jaminan Sosial Nasional}

Istilah jaminan sosial memang sudah sangat popular, namun penyelenggaraan program jaminan sosial itu sendiri substansinya sering di pahami berbeda. Dalam sistem jaminan sosial, manfaat yang diberikan harus memenuhi kriteria tertentu bahwa dengan manfaat tersebut, orang akan memiliki rasa aman (security) sejak lahir hingga meninggal dunia. Jika kriteria tersebut tidak terpenuhi, program jaminan sosial yang di maksudkan itu adalah bantuan sosial (social asistance) atau pelayanan sosial (social services) atau perlindungan sosial lain yang sifatnya temporer.

Menurut Sulastomo (2008: 5) Jaminan sosial nasional adalah upaya mewujudkan kesejahteraan, memberikan rasa aman sepanjang hidup manusia, melalui pendekatan sistem. Peran negara dan masyarakat tergantung filosofi buat apa negara itu didirikan. Sistem jaminan sosial bisa terdiri dari berbagai program. Antara lain, program jaminan kesehatan, program jaminan pemutusan hubungan kerja, program jaminan kecelakaan kerja, program jaminan hari tua, program jaminan pensiun, dan program kematian. Program jaminan sosial lain, bisa diselenggarakan, sesuai dengan kebutuhan, misalnya Jaminan Pendidikan.

Undang-undang Nomor 40 tahun 2004 tentang jaminan sosial nasional menyatakan bahwa system jaminan sosial nasional pada dasarnya merupakan program Negara yang bertujuan memberikan kepastian perlindungan dan kesejahteraan sosial bagi seluruh rakyat Indonesia melalui program ini, setiap penduduk di harapkan dapat memennuhi kebutuhan dasar hidup yang layak apabila terjadi hal-hal yang mengakibatkan hilang atau kurangnya pendapatan, karna menderita sakit, mengalami kecelakaan, kehilangan pekerjaan, memasuki usia lanjut, atau pensiun. Sementara itu, Undang-Undang yang secara khusus mengatur jaminan sosial bagi tenaga kerja swata adalah Undang-undang Nomor 3 Tahun 1992 tentang jaminan sosial tenaga kerja (JAMSOSTEK), yang mencakup program jaminan pemeliharaan kesehatan, jaminan kecelakaan kerja, jaminan hari tua, dan jaminan kematian.

\section{Konsep teori Tenaga Kerja}

Berdasarkan UU No. 3 Tahun 1992, jaminan sosial tenagakerja adalah suatu perlindungan bagi tenaga kerja dalam bentuk santunan berupa uang sebagai pengganti sebagian dari penghasilan yang hilang atau berkurang dann pelayanan sebagai akibat peristiwa atau keadaan yang dialami oleh tenaga kerja berupa kecelakaan kerja, sakit, hamil, bersalin, hari tua dan meninggal dunia. Dalam Peraturan Menteri Tenaga Kerja Nomor: PER04/MEN/1994 tenaga kerja adalah setiap orang yang bekerja pada perusahaan yang belum wajib mengikuti program jaminan sosial tenaga kerja karena adanya pentahapan kepesertaan. 
Payaman dalam A. Hamzah (1990: 24) tenaga kerja (man power) adalah produk yang sudah atau sedang bekerja, atau sedang mencari pekerjaan, serta yang sedang melaksanakan pekerjaan lain.

Terkait konsep tenaga kerja diatas dapat disimpulkan tentang teori-teori ketenagakerjaan yang terbagi menjadi dua teori yang dikemukanan oleh John Maynard Keynes (1936: 57) yaitu sebagai berikut : Teori Keynes (1883-1946) berpendapat bahwa dalam kenyataan pasar tenaga kerja tidak bekerja sesuai dengan pandangan klasik. Dimanapun para pekerja mempunyai semacam serikat kerja (labor union) yang akan berusaha memperjuangkan kepentingan buruh dari penurunan tingkat upah. Teori Tentang Tenaga Kerja, Salah satu masalah yang biasa muncul dalam bidang angkatan kerja seperti yang sudah dibukakan dalam Latar belakang dari pemelihan judul ini adalah ketidak seimbangan akan permintaan tenaga kerja (demand for labor) dan penawaran tenaga kerja (supply of labor), pada suatu tingkat upah. Ketidakseimbangan tersebut penawaran yang lebih besar dari permintaan terhadap tenaga kerja (excess supply of labor) atau lebih besarnya permintaan dibanding penawaran tenaga kerja (excess demand for labor) dalam pasar tenaga kerja.

\section{METODE PENELITIAN}

Jenis penelitian yang di gunakan adalah jenis penelitian kualitatif yaitu data dinyatakan dalm bentuk kata, kalimat, dan gambar atau untuk memberikan gambaran secara jelas mengenai masalah-masalah yang diteliti, menginterprestasikan dan menjelaskan data yang ada secara sistematis.

Tipe penelitian ini adalah fenomenologi yaitu peneliti akan mendeskripsikan pengalaman yang dilakukan dan dialami oleh informan berkaitan dengan transparansi pelayanan JSN Ketenagakerjaan di Kabupaten Gowa.
Sumber data di peroleh dari Data primer yaitu data yang diperoleh melalui hasil observasi dan wawancara, dan data sekunder yaitu data yang dikumpulkan peneliti yang sumbernya dari data-data sebelumnya menjadi seperangkat informasi dalam bentuk dokumen, laporan-laporan, dan informasi tertulis lainnya yang berkaitan dengan objek penelitian. Teknik pengumpulan data yang digunakan adalah observasi, wawancara dan dokumentasi. Teknik analisis data yang digunakan adalah pendekatan deskriptif kualitatif yang diungkapkan dalam bentuk kata, kalimat dan gambar kemudian dikelola dalam bentuk reduksi data, sajian data penarikan kesimpulan dengan menggunakan tiga pengabsahan data yaitu triangulasi dengan sumber data, triangulasi dengan merode, dan triangulasi dengan teori.

\section{HASIL DAN PEMBAHASAN}

\section{Transparansi Pelayanan Jaminan Sosial Nasional (JSN) Ketenagakerjaan di Kabupaten Gowa}

Transparansi merupakan suatu alat yang sangat penting untuk menjembatani kebutuhan masyarakat tentang keingintahuan masyarakat terhadap jalannya pemerintahan didaerah mereka sendiri. Indikator-indikator transparansi adalah sebagai berikut : (1) Penyediaan informasi yang jelas tentang prosedurprosedur, biaya-biaya dan tanggung jawab, (2) Kemudahan akses informasi, (3) Menyusun suatu mekanisme pengaduan jika ada peraturan yang dilanggar atau permintaan untuk membayar uang suap, (4) Meningkatkan arus informasi melalui kerjasama dengan media massa dan lembaga non pemerintah. Demikian halnya dengan transparansi pelayanan JSN Ketenagakerjaan di Kabupaten Gowa, tranparansi pelayanan yang di sajikan oleh pihak BPJS Ketenagakerjaan dalam pelaksanaan pelayanan kepada masyarakat.

\section{a. Penyediaan Informasi}


Dalam melakukan suatu pelayanan publik, penyediaan informasi memiliki fungsi yang sangat berperan karena tanpa adanya informasi yang jelas maka pemberian pelayanan kepada masyarakat akan sulit terealisasi dengan baik. Adapun maksud dari penyediaan informasi itu sendiri adalah sebuah wujud layanan dari salah satu bentuk transparansi dengan indikator informasi prosedur-prosedur yang jelas, biaya-biaya dan tanggung jawab. Berikut hasil kutipan wawancara dengan masyarakat penerima JSN Ketenagakerjaan terkait dengan prosedur pelayanan seperti berikut ini:

"Apa yang dilakukan BPJS
Ketenagakerjaan Kabupaten Gowa
dalam hal transparansi pelayanan
JSN Ketenagakerjaan pada variabel
penyediaan informasi dengan
indikator prosedur-prosedur yang
jelas cukup baik karena sudah
disajikan secara terbuka atau
transparan sehingga
mempermudah para penerima JSN
Ketenagakerjaan apabila sewaktu-
waktu ada perubahan ataupun
informasi baru mengenai program
tersebut". (wawancara AN)

Penyediaan informasi yang dilakukan BPJS Ketenagakerjaan di Kabupaten Gowa sudah cukup terbuka sesuai dengan prinsip transparansi dan indikator transparansi. Kemudian wawancara dilanjutkan dengan pihak dari BPJS Ketenagakerjaan, berikut hasil kutipan wawancara dengan pihak BPJS Ketenagakerjaan terkait dengan prosedur pelayanan:

"Kami dari pihak BPJS
Ketenagakerjaan tidak pernah
mempersulit masyarakat untuk
mengetahui perkembangan
informasi tentang program
tersebut, dalam hal ini informasi
mengenai prosedur-prosedur yang
jelas, BPJS Ketenagakerjaan telah
menyediakan alternatif-alternatif

untuk memperoleh informasi melalui media electronk, media tv, brosur, koran dan webside BPJS Ketenagakerjaan". (Wawancara $M R$ )

Variabel penyediaan informasi dengan indikator penyediaan informasi prosedur-prosedur yang jelas yang dilakukan BPJS Ketenagakerjaan Kabupaten Gowa sudah cukup dilakukan dengan baik sesuai dengan prinsip transparansi. Sebagaimana hasil tanggapan informan dengan berdasar pada indikator di atas dan di sesuaikan dengan hasil wawancara dengan para informan maka transapransi pelayanan dalam hal ini penyediaan informasi pada prosedur-prosedur yang jelas sudah cukup transparan. Selanjutnya hasil kutipan wawancara dengan informan dari pihak BPJS Ketenagakerjaan terkait dengan indikator penyediaan informasi tentang biaya-biaya yang jelas seperti berikut ini:

"BPJS Ketenagakerjaan telah paparkan kepada masyarakat mulai dari proses awal pelayanan JSN Ketenagakerjaan ini hingga persyaratan-persyaratan terkait prosedur dan biaya yang ditujukan kepada masyarakat, terkhusus pada biaya pihak BPJS Ketenagakerjaan mengenai biaya merupakan urusan dapur kantor, cukup tidak cukup harus dicukupkan sesuai dengan keperluan, mengenai biaya yang dibebankan kepada masyarakat semuanya telah dijelaskan di awal mengenai biaya yang dibebankan kemasyarakat". (Wawancara $H L$ )

Terkait biaya-biaya yang jelas semuanya telah dijelaskan dari awal oleh pihak pemerintah kepada masyarakat penerima JSN Ketenagakerjaan sehingga masyarakat dapat mengetahui biaya-biaya yang digunakan sebelum proses pelayanan sampai kepada tahap selanjutnya. Biaya yang digunakan dalam pelayanan JSN 
Ketenagakerjaan di Kabupaten Gowa semua telah diatur oleh masing-masing yang bersangkutan dengan mengambil gaji bulanan tenagakerja sebagai biaya atau iuran dalam pengurusan proses pelayanan JSN Ketenagakerjaan.

\section{b. Kemudahkan akses informasi}

Kemudahan akses informasi adalah kemudahan mendapatkan informasi baik secara langsung maupun tidak langsung. Akses informasi secara langsung yaitu informasi yang didapatkan dengan langsung berhadapan dengan pihak terkait mengenai informasi yang dibutuhkan. Informasi tidak langsung adalah informasi yang didapatkan melaui media perantara seperti penggunaan IT (Information Tecnologi), penggunaan lewat brosur, pamflet dll.

Kemudahan akses informasi tersebut cukup mudah didapatkan atau diakses oleh masyarakat penerima JSN Ketenagakerjaan, pihak BPJS Ketenagakerjaan Kabupaten Gowa juga sangat menyediakan akses informasi yang mudah didapatkan. Selanjutnya hasil wawancara dengan pihak BPJS Ketenagakerjaan di Kabupaten Gowa terkait kemudahan akses informasi secara tidak langsung seperti berikut:

"Penyedian informasi melalui media elektronik, brosur, media tv, koran webside tenagakerja merupakan bentuk informasi tidak langsung yang dan salah satu bentuk layanan dari sebuah instansi terkait dengan kemudahan akses informasi, ini merupakan tanggung jawab yang baik, tetapi informasi melalui media sering terkendala masalah teknis seperti jaringan dan tidak semua pihak mampu menggunakan IT (Information Tecnologi)". (Wawancara HT)

Penyediaan informasi secara tidak langsung melalui media telah dilakukan oleh pihak BPJS Ketenagakerjaan hal ini terbukti karena pihak BPJS Ketenagakerjaan Kabupaten Gowa menyampaikannya dengan cara yang cukup mudah didapatkan oleh masyarakat karena semuanya ada ditengah-tengah masyarakat seperti brosur, tv, dan koran, maka disinilah diperlukan timbal balik yang positif dari masyarakat agar bisa lebih menghargai upaya pemerintah dan memanfaatkannya dengan baik dan tidak dipersalahgunakan untuk kepentingan oknum-oknum yang tidak bertanggung jawab sehingga penyedian dan pemanfaatanya berjalan dengan efektif.

Informasi secara tidak langsung itu disampaikan melalui media namun yang menjadi persoalan dari masyarakat, mereka belajar dari apa yang biasa yang terjadi di lapangan tentang seputar media yang sering timbul kebohongankebohongan kepada publik dan tidak sesuai dengan apa yang terjadi di lapangan atau sering disebut opini dan hanya keperluan media sehingga masyarakat akan berfikir logis tentang informasi yang kurang jelas tersebut kemudian otomatis tingkat kepercayaan masyarakat terhadap instansi atau lembaga yang terkait akan berkurang bahkan bisa hilang.

Terkait kemudahan akses informasi baik secara langsung maupun tidak langsung telah dilakukan, namun kedua cara ini memiliki kelebihan dan kelemahan masing-masing. Kelebihan informasi yang dapat di akses secara langsung adalah kejelasan informasi karena mendapatkan penjelasan yang detail dan disajikan secara terbuka kepada masyarakat hanya sering kali terjadi kesalahpahaman antara penyedia dan penerima informasi ini terjadi karena kurangnya rasa percaya kepada penyedia informasi sementara kelemahannya adalah keberadaan pimpinan untuk memperoleh informasi yang jarang berada di kantor karena kesibukannya seperti melakukan kunjungan-kunjungan ke kantor wilayah, kantor kejaksaan dan asosiasi-asosiasi 
serikat kerja lainnya. Kelebihan informasi yang bisa diakses melalui media adalah informasi yang bisa diakses tanpa membutuhkan waktu yang lama dan tidak mengganggu kegiatan sehari-hari karena sifatnya fleksibel dan melatih masyarakat agar lebih bisa mendalam mengetahui perkembangan teknologi yang ada sementara kelemahannya adalah seringnya penggunaan bahasa yang multi tafsir dan kurang dipahami dan penyampaiannya yang biasa tidak sesuai dengan apa yang terjadi sebenarnya.

\section{c. Menyusun suatu mekanisme pengaduan jika ada peraturan yang dilanggar atau permintaan untuk membayar uang suap}

BPJS Ketenagakerjaan menyediakan bentuk layanan tambahan yang dapat membantu masyarakat dalam proses pemenerimaan pelayanan melalui mekanisme pengaduan, dengan pelayanan tersebut masyarakat dapat melaporkan segala jenis keluhan-keluhan yang mereka rasakan kepada pihak pemerintah melalui sarana pengaduan yang telah disediakan oleh pihak BPJS Ketenagakerjaan seperti, kotak kritik dan saran, melalui nomor telepon kantor yang langsung tersambung dengan instansi atau lembaga tersebut khususnya di BPJS ketenagakerjan Kabupaten Gowa.

Pelayan pengaduan yang disajikan BPJS Ketenagakerjaan karna berbagai fasilitas pengaduan telah disajikan, sehingga memudahkan bagi masyarakat apabila dikemudian hari terdapat kesalahan atau penyimpangan yang mungkin sering muncul di dalam pelaksanaan pelayanan JSN Ketenagakerjaan.

Terkait pelayanan pengaduan, masyarakat belum merasakan keganjalan ataupun kesalahan dalam program ini dan masyarakat hanya mengapreisiasi usaha dari pihak BPJS Ketenagakerjaan terkait usahanya menyediakan sarana-saran tersebut karena tersedianya sarana tersebut apabila dalam pelayanan ini terjadi kesalahan masyarakat dengan mudah mengadukannya sesuai dengan apa yang telah disediakan oleh BPJS Ketenagakerjaan Kabupaten Gowa, harapan masyarakat apabila pengaduan telah dilakukan dapat diproses dengan cepat sehingga sarana yang telah disediakan tersebut bukan hanya sekedar formalitas semata.

Jadi penyusunan mekanisme pengaduan tersebut telah terealisasi sebagai salah satu indikator dalam transparansi, dan mungkin selanjutnya diserahkan kepada masyarakat bagaimana menyikapi hal tersebut dan dapat dimanfaatkan dengan baik sehingga hubungan tersebut dapt singkron sesuai dengan apa yang diharapkan dari kedua belah pihak dan yang terpenting agar antara masyarakat dan pemerintah dapat menjadi mitra dan bekerja sama dengan baik meskipun di luar dari hal ini.

\section{d. Meningkatkan arus informasi melalui kerja sama dengan media massa dan kerja sama dengan lembaga non pemerintah}

Meningkatkan arus informasi melalui kerjasama media massa dan lembaga non pemerintah adalah salah satu prinsip transparansi pelayanan JSN Ketenagakerjaan. Untuk mengukur sejauh mana prinsip transparansi tersebut pada, Pelayanan BPJS Ketenagakerjaan digunakan indikator sebagai berikut: (1) Kerjasama melalui media massa; (2) Kerjasama melalui media massa akan mempermudah masyarakat untuk mengetahui perkembangan tentang pelayanan JSN Ketenagakerjaan, dengan terjalinnya kerjasama tersebut otomatis arus informasi akan sampai ke masyarakat sehingga informasi bisa hadir ditengahtengah masyarakat dan otomatis masyarakat tidak lagi ketinggalan informasi. 
BPJS Ketenagakerjaan telah melakukan upaya yang maksimal terbukti dari hasil kerjasamanya dengan berbagai media cetak, dengan kerjasama tersebut akan lebih mempermudah masyarakat dalam menghimpun informasi mengenai pelayanan dan seputar informasi program tersebut dan masyarakat tidak menjadikan kekurangan informasi sebagai alasan untuk tidak mengetahui seputar informasi tersebut karena semua itu telah terpecahkan dengan kerjasama BPJS Ketenagakerjaan Kabupaten Gowa.

Masyarakat banyak berharap dari hasil kerjasama BPJS Ketenagakerjaan dengan media massa, karena dengan adanya kerjasama tersebut otomatis informasi akan terus mengalir ke lingkungan masyarakat selama beritanya sesuai dengan apa yang terjadi di lapangan dan bukan kebohongan publik karena masyarakat memerlukan informasi yang banyak dan sesuai dengan fakta yang terjadi kemudian seterusnya informasi tersebut disampaikan setiap terdapat perkembangan-perkembangan seputar pelayanan JSN Ketenagakerjaan dan terpenting tidak lagi terdapat keraguraguan dari masyarakat tentang langkah yang dilakukan instansi pemerintah dan lembaga.

BPJS Ketenagakerjaan dalam menciptakan transparansi, salah satunya dengan menjalin kerjasama dengan berbagai media cetak guna mempermudah masyarakat dalam mendapatkan informasi sesuai dengan apa yang terjadi dan bukan semata-mata kebohongan kepada publik, dari bentuk kerjasama yang terjalin tersebut jelaslah bagaimana upaya-upaya yang telah dilakukan BPJS Ketenagakerjaan demi terciptanya transparansi kepada masyarakat yang selama ini menjadi tanda tanya masyarakat karena rasa penasarannya tersebut hal ini tentunya menjadikan instansi atau lembaga tersebut frekuensi positifnya makin meningkat.
Kerjasama yang dilakukan oleh BPJS Ketenagakerjaan dengan lembaga non pemerintah telah tercipta yaitu kerjasama yang terjalin dengan asosiasi-asosiasi perusahaan dimana tujuan dari kerjasama itu adalah semata-mata untuk kepentingan masyarakat dalam mendapatkan perlindungan ganda selain itu dengan kerja sama tersebut maka hak-hak para pekerja tetap terjamin apabila nantinya terjadi hal yang tidak diinginkan seperti PHK, diskriminatif serta permasalahan lainnya yang sering timbul didalamnya, maka disinilah peran dari lembaga non pemerintah.

Bentuk kerjasama yang dilakukan dengan lembaga non pemerintah telah terjalin dengan baik dalam hal memberikan naungan bagi pekerja jika terjadi diskriminasi PHK bagi pekerja. Jadi para pekerja tersebut mendapatkan perlindungan ganda yaitu dari pihak pemerintah dan juga dari pihak non pemerintah. Melihat bentuk kerjasama yang terjalin antara BPJS Ketenagakerjaan dengan lembaga non pemerintah, peserta JSN Ketenagakerjaan ini sangat terbantu karena haknya sebagai pekerja bisa terlindungi, sehingga jika ada sesuatu buruk yang menimpa tenagakerja maka mereka berhak atas perlindungan dari pemerintah dan non pemerintah.

Prinsip transparansi dengan indikator meningkatkan arus informasi melalui kerja sama dengan media massa dan lembaga non pemerintah sudah dilakukan dengan baik oleh BPJS Ketenagakerjaan di Kab Gowa Hal ini selaras dengan pemaparan Dr. Gopakumar Krishnan yaitu Akses informasi merupakan kemampuan warga Negara untuk mendapatkan informasi mengenai aktivitas pemerintahan di masa dulu, sekarang dan masa depan. Istilah kebebasan informasi juga secara luas digunakan ketika dihubungkan dengan kemampuan individu untuk mendapatkan akses terhadap informasi yang dimiliki oleh Negara. Akses informasi secara 
fundamental berkaitan dengan kualitas informasi yang disediakan oleh Negara, bukan tentang kuantitas. Itu telah ditekankan bahwa akses informasi merupakan elemen yang esensial dari pemerintahan yang demokratis yaitu demokrasi untuk berkembang, warga Negara harus mendapatkan informasi yang cukup kebijakan dan kinerja pemerintah.

\section{Upaya Pemerintah dalam Mewujudkan Transparansi Pelayanan JSN Ketenagakerjaan di Kabupaten Gowa}

Upaya konkrit untuk mewujudkan transparansi pelayanan JSN Ketenagakerjaan oleh BPJS Ketenagakerjaan Kabupaten Gowa adalah sebagai berikut:

a. Pembuatan webside kantor BPJS Ketenagakerjaan;

Pembuatan website adalah salah satu terobosan baru yang dilakukan oleh BPJS Ketenagakerjaan agar masyarakat dapat mengakses dengan mudah informasi yang dibutuhkan dan masyarakat juga dapat melihat semua agenda atau kegiatan yang dilakukan oleh BPJS Ketenagakerjaan. Berikut hasil kutipan wawancara dengan informan terkait dengan upaya yang dilakukan dalam pengelolaan keuangan daerah agar transparansi seperti berikut ini:

"BPJS Ketenagakerjaan
menyediakan webside terkait
pelayanan JSN Ketenagakerjaan
yang bertujuan untuk
menyampaikan segala informasi
yang dibutuhkan oleh masyarakat
penerima JSN Ketenagakerjaan,
segala jenis informasi yang
dibutuhkan dapat dilihat pada
webside dengan situs
www.bpjs.ketenagakerjaan.go.id".(
wawancara HT)

Upaya yang dilakukan oleh BPJS Ketenagakerjaan itu semua merupakan upaya yang baik dan pasti masyarakat bisa menilai sejauh mana usaha yang dilakukaan oleh BPJS Ketenaagakerjaan agar dapat menjadi lembaga yang transparaan dan dapaat dipercaya oleh masyarakat dan tidak menimbulkan pertanyaan di lingkungan masyarakat.

Terkait pembuatan webside kantor, masyarakat belum tahu persis tentang webside kantor tersebut berhubung karena masyarakat belum bisa menggunakan internet karena faktor ketinggalan terhadap kemajuan teknologi jadi otomatis apa yang telah dilakukan BPJS Ketenagakerjaan dalam pembuatan webside kantor belum seluruhnya masyarakat bisa memanfaatkannya. Tetapi bukan berarti apa yang telah dilakukan BPJS Ketenagakerjaan tersebut tidak sampai ke masyarakat karena ini hanya faktor SDMnya seseorang yang berbeda yang terpenting adalah upaya itu sudah dilakukan.

b. Pelayanan satu atap;

Selain pembuatan web, BPJS Ketenagakerjaan pun melakukan pelayanan satu atap untuk mempermudah masyarakat dalam mengurus berkas yang diperlukan. Hadirnya pelayanan satu atap masyarakat akan sangat terbantu karena tidak mempersulit masyarakat dalam melakukan berbagai pengurusan jadi masyarakat tidak perlu lagi ragu-ragu dalam memerlukan pelayanan.

c. Penyediaan pelayanan One Day Service

Penyediaan pelayanan One Day Service merupakan terobosan baru dalam instansi ataupun lembaga pemerintah yang bertujuan untuk memberi kemudahan bagi masyarakat dalam proses pelayanan dimana ini merupakan layanan satu hari yang diproses kurang dari 30 menit sampai satu jam, selain itu juga mempersingkat alur birokrasi, dan mewujudkan harapan masyarakat pengguna layanan serta mewujudkan komitmen pemberi pelayanan dalam memberikan pelayanan yang tepat dan cermat. Dalam pelayanan JSN Ketenagakerjaan, BPJS Ketenagakerjaan 
Kabupaten Gowa juga menyediakan pelayanan One Day Service dengan harapan dapat memperrmudah para tenagakerja dalam memperoleh pelayanan. Berikut hasil wawancara dengan informan mengenai pelayanan One Day Service seperti berikut ini :

"Kami juga menyediakan pelayanan One Day Service untuk pelayanan JSN Ketenagakerjaan, mengenai pelayanan One Day Service intinya semua pelayanan atau urusan tak boleh lebih dari satu hari, jika data lengkap proses pengurusan tak boleh lebih dari 30 menit". (wawancara $H L)$

Pelayanan One Day Service merupakan cara yang jitu dalam melaksanakan pelayanan khususnya untuk pelayanan di BPJS Ketenagakerjaan di Kabupaten Gowa, karena dengan cara ini masyarakat akan merasa terbantu apa lagi untuk masyarakat yang memiliki kesibukan yang banyak, jadi dengan pelayanan ini masyarakat akan paham langsung karena penyajiannya yang secara transparansi atau terbuka. Selanjutnya anggapan masyarakat terkait pelayanan One Day Service melalui wawancara seperti berikut:

"Dari saya pribadi mengenai pelayanan One Day Service, saya sudah rasakan hasilnya memang bagus karna prosesnya cepat, tapi yang jadi masalah biasanya banyak masyarakat yang antusias dengan pelayanan ini otomatis pihak dari BPJS Ketenagakerjaan itu kuwalahan menghadapi antrian yang begitu banyak sehingga terkadang pelayanan One Day Service ini tidak efektif". (wawancara AD).

Pelayanan One Day Service yang disediakan oleh BPJS Ketenagakerjaan Kabupaten Gowa telah dirasakan oleh masyarakat penerima JSN Ketenagakerjaan namun pelayanan tersebut memiliki kelebihan dan kelemahan masing-masing, kelebihan dari pelayanan One Day Service yaitu mempercemat dan mempermudah bagi pemberi daan penerima pelayanan dalam memperoleh JSN Ketenagakerjaan sedangkan yang menjadi kelemahan dari pelayanan One Day Service yaitu karena minat yang semakin meningkat dari masyarakat untuk memperoleh pelayanan tersebut mengakibatkan antrian panjang sehingga membuat para pemberi pelayanan kuwalahan dan pelayanan One Day Service tersebut menjadi tidak efektif lagi seperti apa yang diharapkan.

\section{E. PENUTUP}

Tranparansi pelayanan JSN Ketenagakerjaan di Kabupaten Gowa dengan indikator: (a) penyediaan informasi dengan indikator kejelasan prosedurprosedur dan kejelasan biaya-biaya sudah transparan dengan melakukan suatu pelayanan publik yang sesuai dengan apa yang dibutuhkan oleh penerima pelayanan, penyediaan informasi memiliki fungsi yang sangat berperan karena tanpa adanya informasi yang jelas maka pemberian pelayanan kepada masyarakat akan sulit terealisasi dengan baik; (b) Kemudahan akses informasi dengan indikator kemudahan mendapatkan informasi langsung maupun tidak langsung telah dilakukan oleh pihak pemerintah kepada masyarakat, untuk mendapatkan kemudahan dalam memperoleh informasi terkait pelayanan JSN Ketenagakerjaan di Kabupaten Gowa masyarakat penerima JSN Ketenagakerjaan berhak atas informasi yang dapat menguntungkan dirinya seebagai tenagakerja agar apa yang menjadi tujuannya dapat terwujud sesuai rencana mereka; (c) Menyusun suatu mekanisme pengaduan jika ada peraturan yang dilanggar atau permintaan untuk membayar uang suap dengan indikator layanan pengaduan sudah dilakukan dengan baik dan dapat diterima oleh masyarakat dengan baik pula, dengan mekanisme pengaduan tersebut masyarakat dapat melaporkan segala jenis 
keluhan-keluhan yang mereka rasakan kepada pihak pemerintah melalui sarana pengaduan yang telah disediakan oleh pihak yang terkait dalam hal ini BPJS Ketenagakerjaan seperti, kotak kritik dan saran, melalui nomor telepon kantor yang langsung tersambung dengan BPJS ketenagakerjan Kabupaten Gowa; (d) Meningkatkan arus informasi melalui kerjasama dengan media massa dan lembaga non pemerintah sudah dilakukan dengan baik sesuai kebutuhan para tenagakerja, kerjasama yang dilakukan oleh BPJS Ketenagakerjaan dengan media massa dan lembaga non pemerintah semata-mata hanya untuk meningkatkan kualitas pelayanan yang akan diberikan kepada masyarakat sehingga masyarakat mendapatkan kepuasan dalam pelayanan.

Upaya yang dilakukan oleh BPJS Ketenagakerjaan sejauh ini adalah memberikan informasi terkait JSN Ketenagakerjaan melalui 3 langkah yaitu (1) pembuatan webside tenagakerja; (2) Pelayanan satu atap; dan (3) Pelayanan One Day Service, Pelayanan ini bertujuan untuk memberi kemudahan bagi masyarakat dalam proses pelayanan, mempersingkat alur birokrasi, dan mewujudkan harapan masyarakat pengguna layanan serta mewujudkan komitmen pemberi pelayanan dalam memberikan pelayanan yang tepat dan cermat.

\section{DAFTAR PUSTAKA}
Ali, Faried. 2011. Teori dan Konsep Administrasi (Dari Pemikiran Pardigmatik Menuju Redefenisi). Jakarta : Rajawali Pers.

Andrianto, N. 2007. Good e-Governance : Transparansi dan Akuntabilitas Publik melalui e-Government. Malang: Bayumedia Publishing.
Anonim. 2013. Pedoman Penulisan Proposal Penelitian dan Skripsi, Makassar : Fisipol unismuh Makassar.

Hardjasoemantri, Koesnadi. 2003. Good Governance Dalam Pembangunan Berkelanjutan Di Indonesia, Yogyakarta : Pustaka Pelajar.

Logos, 2003. Transparansi, Akuntabilitas, dan Kontrol Dalam Pembiayaan Pertahanan (Problem dan Rekomendasi). Yogyakarta : PT Gramedia.

Mardiasmo. 2009. Otonomi dan Manajemen Keuangan Daerah, Yogyakarta: Penerbit Andi.

Moenir, H.A.S. 2008. Manajemen Pelayanan Umum di Indonesia, Jakarta : Bumi Aksara.

Sugiyono. 2012. Metode Penelitian Kuantitatif, Kualitatif dan $R$ \& D, Bandung : Alfabeta.

\section{Dokumen}

Undang-Undang Nomor 40 Tahun 2004 tentang jaminan sosial nasional

Peraturan perundang-undangan Republik Indonesia Nomor 12 Tahun 2013 Tentang Jaminan Kesehatan. 